\title{
33. PHYSICAL PROPERTIES OF BASALTS FROM DSDP LEG 55
}

\author{
Masaru Kono and Yozo Hamano, Geophysical Institute, University of Tokyo, Tokyo 113, Japan \\ and \\ W. Jason Morgan, Department of Geological Sciences, Princeton University, Princeton, New Jersey
}

\section{INTRODUCTION}

Four seamounts in the Emperor Seamount chain were drilled during DSDP Leg 55. Holes 430A (Ōjin Seamount), 432A (Nintoku), and 433A, 433B, and 433C (Suiko) reached volcanic basement; in particular, Hole $433 \mathrm{C}$ penetrated 390 meters of basaltic layers, of which 250 meters was recovered. The basalts from these holes constitute almost the only available samples from seamount interiors, although many samples from seamount surfaces had previously been obtained by dredging. Below a thin sediment cover, the seamounts are probably comprised mostly of extrusive and some intrusive volcanic rocks. Geophysical anomalies (gravity, magnetism, etc.) caused by some seamounts have been studied intensively and hypotheses advanced to explain them. Measurements of various physical and magnetic properties of these basalts are therefore of considerable interest in interpreting such anomalies.

Petrological studies (Kirkpatrick et al., this volume) and magnetic studies (Kono, this volume) confirm that these basalts erupted subaerially and that they are quite similar in composition to the basalts found on the Hawaiian Islands. Moreover. the ages of Ōjin, Nintoku, and Suiko seamounts $(55,56$, and 65 m.y., respectively: Dalrymple et al., this volume) correlate well with an 8 $\mathrm{cm} /$ year rate of movement of the Pacific plate over the Hawaiian hot spot. It seems likely, therefore, that these basalts have physical properties very similar to those of Hawaiian basalts.

In this chapter, we report the results of physical property measurements and discuss their implications. In particular, we will compare these data with measurements on normal oceanic basalts (Hyndman and Drury, 1976; Hamano, in press) and on Hawaiian basalts (Robertson and Peck, 1974). The physical properties measured are bulk density $(\varrho)$, porosity $(\phi)$, compressional velocity $\left(\mathrm{V}_{\mathrm{p}}\right)$, shear velocity $\left(\mathrm{V}_{\mathrm{s}}\right)$, thermal conductivity $(\varkappa)$, and electrical resistivity $\left(\sigma^{-1}\right)$. Other quantities such as grain density, Poisson's ratio $(\nu)$, and other elastic constants can be calculated from these data. All measurements except that of porosity were carried out on salt-water-saturated samples, since the in-situ properties of these rocks are of interest from the geophysical point of view.

\section{EXPERIMENTAL METHODS}

Measurements were made on minicore samples $2.5 \mathrm{~cm}$ in diameter and about $2.3 \mathrm{~cm}$ long, both on the
Glomar Challenger and in our Tokyo laboratory. Samples were kept in salt water between measurements to preserve the in-situ condition.

On board the Glomar Challenger, bulk density and compressional wave velocity were measured. Bulk density was determined by a two-minute count on the Gamma Ray Attenuation Porosity Evaluator (GRAPE), with an estimated accuracy of \pm 2 per cent. Compressional wave velocity was measured using the Hamilton Frame velocimeter. For some of the samples, velocity was measured in both the horizontal (axis of the minicore) and vertical (across minicore diameter) directions. The differences between horizontal and vertical velocity were mostly within a few per cent and always smaller than about 5 per cent. This suggests that these basalts have isotropic elastic properties. Velocity measurement on board was reproducible to within about 2 per cent.

In our Tokyo laboratory, we measured porosity, bulk density, compressional velocity, shear velocity, thermal conductivity, and electrical resistivity. Bulk density was measured by the conventional immersion technique, with an estimated accuracy of 0.5 per cent. Porosity was determined for each sample after all the other measurements were finished. Samples were heated to $120^{\circ} \mathrm{C}$ and kept at that temperature for 24 hours. Porosity was calculated from the difference between the weight of the original, salt-water-saturated sample and the weight after drying. The porosity thus determined may be a minimum estimate (Hyndman and Drury, 1977). That grain density is independent of porosity (Figure 1) shows, however, that the porosity estimates are adequate.

To determine elastic-wave velocities, we used a standard pulse transmission method with $2-\mathrm{MHz}$ (for $\mathrm{V}_{\mathrm{p}}$ ) and $1-\mathrm{MHz}$ (for $\mathrm{V}_{\mathrm{s}}$ ) transducers. The higher frequency (compared with the Hamilton Frame [400 kHz]), as well as the better shape of shore samples, gave better accuracy, about \pm 1 per cent.

We measured electrical resistivity using a commercial AC bridge. Because the frequency dependence of a saltwater-saturated sample is small in a frequency range of $100 \mathrm{~Hz}$ to $1 \mathrm{MHz}$ (Katsube et al., 1977), we used a single frequency of $1 \mathrm{kHz}$, and our measurements are accurate to within about \pm 5 per cent. Thermal conductivity was measured on a QTM-1 thermal conductivity meter (Showa Denko Ltd.) which uses a modified needle method. Accuracy of measurement is difficult to estimate, but the nominal precision of this apparatus is \pm 5 per cent, and the reproducibility was better than a few per cent. 


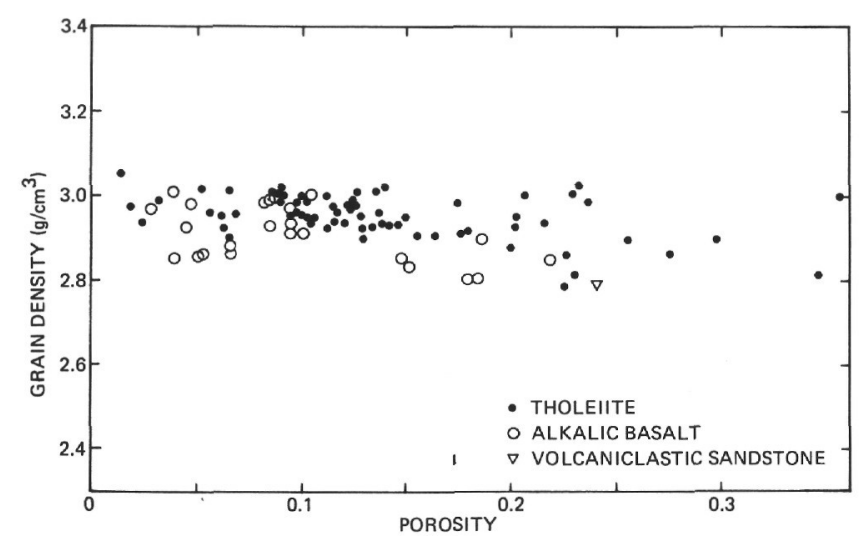

Figure 1. Porosity dependence of grain density.

\section{RESULTS}

Results of the shipboard measurements are shown in the Site Reports (this volume). Shore-based experimental data are summarized in Table 1 of this chapter. Figure 2 shows histograms of measured physical properties. The distribution of $V_{p}$ values obtained on board (dashed line in Figure 2) disagrees substantially with that of values determined in our laboratory, although the distributions of densities are similar. The $\mathrm{V}_{\mathrm{p}}$ measured on board may be systematically smaller than the real value. Accordingly, the discussions to follow are based solely on the shore-based experiments.

Table 2 summarizes the differences between physical properties of tholeiites and alkalic basalts (including hawaiites). Tholeiites have smaller means for all the measured physical properties except thermal conductivity, but the differences are not significant, and are caused mainly by differences in porosity; tholeiitic rocks contain more pores than do alkalic basalts.

\section{Porosity Dependence of the Measured Physical Properties}

The physical properties measured cover wide ranges of values, as shown in Figure 2. To make clear the origin of this wide dispersion, we have plotted the following properties as functions of porosity: bulk density (Figure 3 ), grain density (Figure 1), compressional- and shearwave velocities (Figures 4 and 5), thermal conductivity (Figure 6), and electrical resistivity (Figure 7). These physical properties, except grain density, correlate strongly with the porosity measured on the same specimen. This suggests that the volume of pores or fractures saturated with salt water is mainly responsible for the variation of these physical properties. The similar chemical and mineral compositions of the seamount basalts (Kirkpatrick et al., this volume) confirm this interpretation; to examine further its validity, we shall now discuss separately the relationship between porosity and each measured physical property.

\section{Bulk Density and Grain Density}

Figure 3 indicates a very strong correlation between bulk density and porosity for a wide range of porosity ( 2 to $35 \%$ ). A linear decrease in density with increasing porosity is theoretically expected if the variation is caused by the difference in pore volume. A least-squares fit of the data gives a linear relation of $\varrho$ (bulk density, $\left.\mathrm{g} / \mathrm{cm}^{3}\right)=2.99-2.20 \phi$ (porosity), with a high correlation factor of $R=0.974$. The high correlation factor and the constancy of the grain density (Figure 1) confirm the above interpretation.

The slope of the density-versus-porosity plot is slightly higher than the theoretical estimate, as has also been observed for normal sea-floor basalts (Hamano, in press). Underestimation of the porosity, or some lowdensity secondary minerals filling some of the pores, may cause such a difference (Hamano, in press).

In Figures 1 and 3, tholeiitic and alkalic basalts are identified by different symbols. The porosity dependencies of bulk density and grain density for each basalt type are not significantly different. Data for one volcaniclastic sandstone suggest that the sandstone consists of material derived from these basaltic rocks.

\section{Compressional- and Shear-Wave Velocities}

Porosity dependencies of compressional- and shearwave velocities are shown in Figures 4 and 5, respectively. The velocities also tend to decrease with increasing porosity. Theoretical estimates of elastic properties of composite materials have been studied extensively. Watt et al. (1976) reviewed the previous studies. In the present case we can assume that the samples consist of two phases: solid rock and salt water. Among the theories treating the two-phase material, bounding theories, such as Voigt and Reuss bounds (Hill, 1963) or Hashin and Strikman bounds (Hashin and Strikman, 1963), give a broad constraint if one of the phases has a vanishingly small elastic constant. The bounds are so broad as to be practically useless to us here. In contrast, a deterministic theory, such as that of Walsh (1973) or of Kuster and Toksoz (1974), will give some information on the configuration of pores and cracks in the samples, as well as the intrinsic (pore-free) property of the rocks. Analysis along these lines is still in progress in our laboratory.

The relation between compressional- and shear-wave velocities is shown in Figure 8. The correlated variation of both velocities indicates the same mechanism for the velocity change. Poisson's ratio increases from about $0.29\left(\mathrm{~V}_{\mathrm{p}}=6.3 \mathrm{~km} / \mathrm{s}\right)$ to $0.36\left(\mathrm{~V}_{\mathrm{p}}=3.3 \mathrm{~km} / \mathrm{s}\right)$ with decrease of the velocities. The variation is consistent with the assumption that the increase of the water content causes the velocity decrease.

\section{Thermal Conductivity}

The relation between thermal conductivity and porosity is given in Figure 6. Although the distribution of data points is not so systematic as for the other physical properties, correlation is apparent. Robertson and Peck (1974) measured the thermal conductivity of Hawaiian vesicular basalt with porosity ranging from 2 to 98 per cent. Their data for water-saturated rocks within the present porosity range are also plotted in Figure 6. The two sets of data reveal no systematic disagreement; this 
TABLE 1

Physical Properties of Basalts from DSDP Leg 55

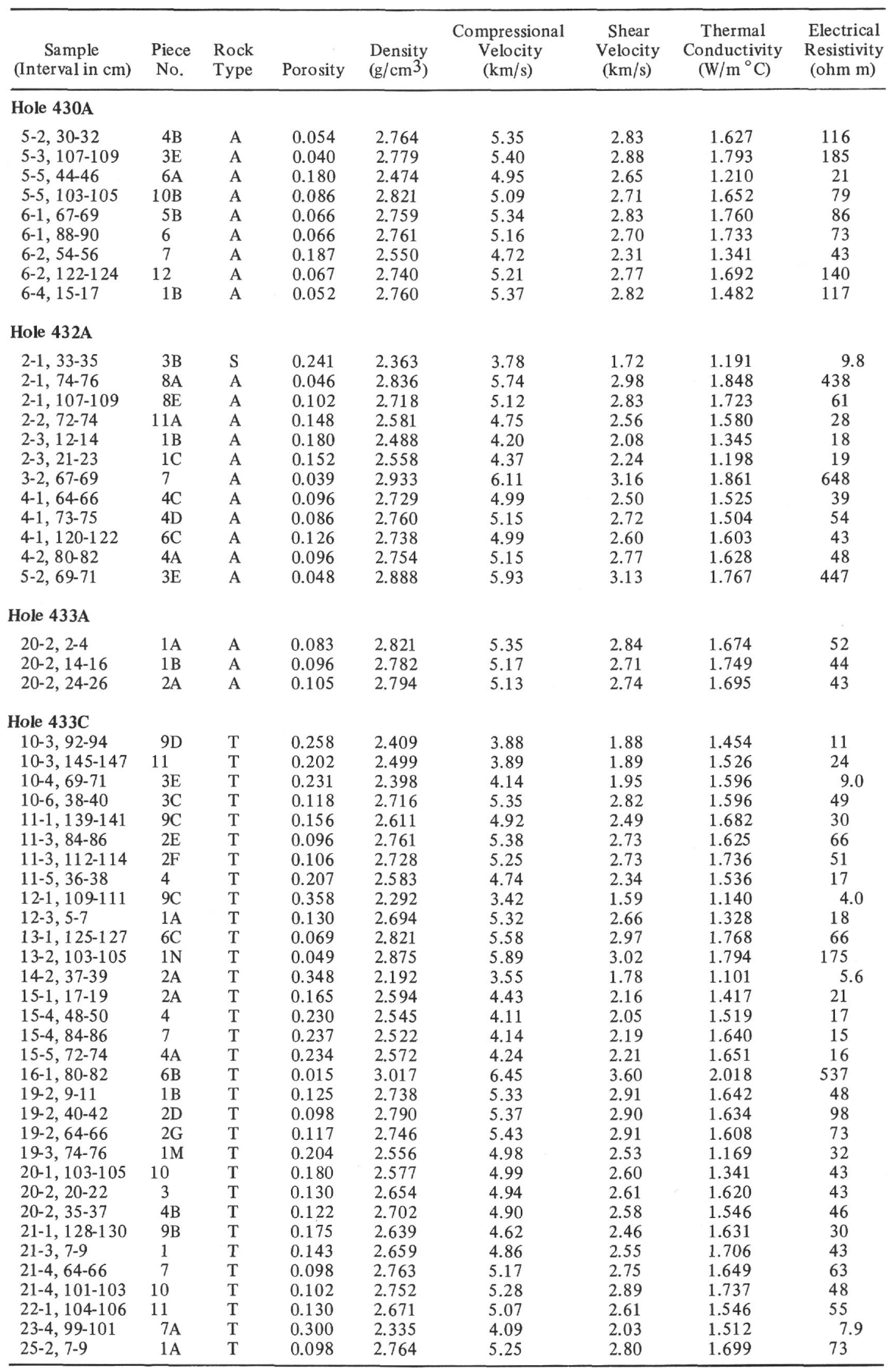


TABLE 1 - Continued

\begin{tabular}{|c|c|c|c|c|c|c|c|c|}
\hline $\begin{array}{c}\text { Sample } \\
\text { (Interval in } \mathrm{cm})\end{array}$ & $\begin{array}{l}\text { Piece } \\
\text { No. }\end{array}$ & $\begin{array}{l}\text { Rock } \\
\text { Type }\end{array}$ & Porosity & $\begin{array}{l}\text { Density } \\
\left(\mathrm{g} / \mathrm{cm}^{3}\right)\end{array}$ & $\begin{array}{l}\text { Compressional } \\
\text { Velocity } \\
(\mathrm{km} / \mathrm{s})\end{array}$ & $\begin{array}{l}\text { Shear } \\
\text { Velocity } \\
(\mathrm{km} / \mathrm{s})\end{array}$ & $\begin{array}{c}\text { Thermal } \\
\text { Conductivity } \\
\left(\mathrm{W} / \mathrm{m}^{\circ} \mathrm{C}\right)\end{array}$ & $\begin{array}{l}\text { Electrical } \\
\text { Resistivity } \\
\text { (ohm m) }\end{array}$ \\
\hline \multicolumn{9}{|l|}{ Hole 433C } \\
\hline $25-2,27-29$ & $1 \mathrm{~B}$ & $\mathrm{~T}$ & 0.104 & 2.743 & 5.15 & 2.66 & 1.635 & 55 \\
\hline $25-2,54-56$ & $1 \mathrm{E}$ & $\mathrm{T}$ & 0.151 & 2.658 & 5.03 & 2.62 & 1.455 & 43 \\
\hline $25-5,103-105$ & $1 \mathrm{H}$ & $\mathrm{T}$ & 0.102 & 2.789 & 5.46 & 2.92 & 1.861 & 73 \\
\hline $26-5,94-96$ & 1I & $\mathrm{T}$ & 0.063 & 2.827 & 5.29 & 2.79 & 1.834 & 127 \\
\hline $26-6,129-131$ & $7 \mathrm{~A}$ & $\mathrm{~T}$ & 0.136 & 2.673 & 4.95 & 2.52 & 1.681 & 37 \\
\hline $27-5,41-43$ & 1D & $\mathrm{T}$ & 0.177 & 2.579 & 4.32 & 2.20 & 1.529 & 15 \\
\hline $28-4,121-123$ & $8 \mathrm{~A}$ & $\mathrm{~T}$ & 0.203 & 2.539 & 4.98 & 2.83 & 1.460 & 29 \\
\hline $29-2,115-117$ & 16 & $\mathrm{~T}$ & 0.113 & 2.771 & 5.18 & 2.59 & 1.683 & 47 \\
\hline $31-4,83-85$ & $3 \mathrm{~B}$ & $\mathrm{~T}$ & 0.227 & 2.441 & 4.15 & 1.86 & 1.610 & 7.9 \\
\hline $32-1,38-40$ & $3 \mathrm{~B}$ & $\mathrm{~T}$ & 0.226 & 2.383 & 3.48 & 1.64 & 1.475 & 10 \\
\hline $35-1,112-114$ & $1 \mathrm{M}$ & $\mathrm{T}$ & 0.136 & 2.739 & 5.00 & 2.66 & 1.862 & 61 \\
\hline $35-6,48-50$ & $1 \mathrm{E}$ & $\mathrm{T}$ & 0.033 & 2.922 & 6.06 & 3.16 & 1.950 & 662 \\
\hline $35-6,121-123$ & 10 & $\mathrm{~T}$ & 0.217 & 2.520 & 4.63 & 2.33 & 1.679 & 19 \\
\hline $35-7,116-118$ & $5 \mathrm{~A}$ & $\mathrm{~T}$ & 0.141 & 2.740 & 5.08 & 2.69 & 1.652 & 34 \\
\hline $36-1,45-47$ & $1 \mathrm{E}$ & $\mathrm{T}$ & 0.126 & 2.739 & 5.21 & 2.69 & 1.829 & 32 \\
\hline $36-1,105-107$ & $3 \mathrm{~A}$ & $\mathrm{~T}$ & 0.277 & 2.354 & 4.36 & 2.12 & 1.421 & 9.5 \\
\hline $36-3,60-62$ & $1 \mathrm{H}$ & $\mathrm{T}$ & 0.114 & 2.706 & 4.81 & 2.35 & 1.767 & 27 \\
\hline $36-4,56-58$ & $1 \mathrm{G}$ & $\mathrm{T}$ & 0.123 & 2.729 & 4.78 & 2.31 & 1.723 & 26 \\
\hline $36-5,29-31$ & 1D & $\mathrm{T}$ & 0.140 & 2.667 & 4.78 & 2.47 & 1.751 & 28 \\
\hline $37-3,74-76$ & $1 \mathrm{~J}$ & $\mathrm{~T}$ & 0.091 & 2.807 & 5.31 & 2.85 & 1.895 & 52 \\
\hline $38-1,57-59$ & $1 \mathrm{~F}$ & $\mathrm{~T}$ & 0.025 & 2.887 & 6.07 & 3.16 & 1.998 & 1241 \\
\hline $38-5,119-121$ & $1 Q$ & $\mathrm{~T}$ & 0.064 & 2.802 & 5.47 & 2.89 & 1.873 & 104 \\
\hline $39-5,96-98$ & $1 \mathrm{D}$ & $\mathrm{T}$ & 0.020 & 2.937 & 6.27 & 3.34 & 2.013 & 989 \\
\hline $39-6,78-80$ & 1D & $\mathrm{T}$ & 0.057 & 2.846 & 5.77 & 3.03 & 1.900 & 200 \\
\hline $41-1,51-53$ & $1 \mathrm{E}$ & $\mathrm{T}$ & 0.103 & 2.783 & 5.22 & 2.84 & 1.828 & 45 \\
\hline $42-1,68-70$ & $1 \mathrm{G}$ & $\mathrm{T}$ & 0.127 & 2.734 & 5.08 & 2.69 & 1.821 & 40 \\
\hline $42-2,136-138$ & $6 \mathrm{E}$ & $\mathrm{T}$ & 0.130 & 2.700 & 5.18 & 2.72 & 1.759 & 43 \\
\hline $42-5,134-136$ & $1 \mathrm{~N}$ & $\mathrm{~T}$ & 0.092 & 2.815 & 5.25 & 2.95 & 1.770 & 38 \\
\hline $43-1,33-35$ & $1 \mathrm{~B}$ & $\mathrm{~T}$ & 0.091 & 2.835 & 5.23 & 2.80 & 1.838 & 45 \\
\hline $44-1,41-43$ & $1 \mathrm{E}$ & $\mathrm{T}$ & 0.066 & 2.881 & 5.48 & 2.91 & 1.889 & 82 \\
\hline $44-4,108-110$ & 4 & $\mathrm{~T}$ & 0.128 & 2.752 & 4.89 & 2.71 & 1.732 & 33 \\
\hline $45-2,45-47$ & 1D & $\mathrm{T}$ & 0.088 & 2.827 & 5.19 & 2.86 & 1.866 & 54 \\
\hline $45-5,51-53$ & $1 \mathrm{D}$ & $\mathrm{T}$ & 0.053 & 2.911 & 5.76 & 3.18 & 1.921 & 95 \\
\hline $45-6,43-45$ & $1 \mathrm{C}$ & $\mathrm{T}$ & 0.108 & 2.736 & 4.94 & 2.67 & 1.705 & 27 \\
\hline $46-3,54-56$ & $2 \mathrm{~B}$ & $\mathrm{~T}$ & 0.118 & 2.733 & 5.02 & 2.69 & 1.662 & 59 \\
\hline $47-1,26-28$ & $2 \mathrm{~A}$ & $\mathrm{~T}$ & 0.087 & 2.834 & 5.27 & 2.81 & 1.829 & 43 \\
\hline $47-5,25-27$ & $3 \mathrm{~A}$ & A & 0.220 & 2.449 & 4.43 & 2.37 & 1.560 & 30 \\
\hline $48-3,30-32$ & $1 \mathrm{C}$ & A & 0.028 & 2.917 & 5.98 & 3.20 & 1.940 & 497 \\
\hline $49-1,142-144$ & 8B & $\mathrm{T}$ & 0.147 & 2.657 & 5.13 & 2.65 & 1.672 & 26 \\
\hline $49-2,50-52$ & $1 \mathrm{H}$ & $\mathrm{T}$ & 0.138 & 2.693 & 5.04 & 2.51 & 1.831 & 24 \\
\hline
\end{tabular}

is compatible with petrologic studies on seamount samples under discussion (Kirkpatrick et al., this volume). As pointed out by Robertson and Peck (1974), thermal conductivity of their high-porosity ( $\gtrsim 10 \%)$ samples can be explained reasonably well by a theoretical estimate of the pore effect. The observed thermal conductivity of the low-porosity basalts, however, is appreciably smaller than the conductivity determined from fully solid rock. They attributed the discrepancy to the insulating effect of micropores and thin microfractures, and obtained a prediction formula for these low-porosity rocks by applying an empirical correction factor. The similarity between their data and our thermal conductivity data here suggests not only that conductivity is determined mainly by the water content of the samples, but also that the intrinsic conductivity of the fully solid rock of our seamount samples is quite similar to that of the Hawaiian basalts.
Figure 6 indicates that the conductivity of alkalic basalts is somewhat lower than that of tholeiitic basalts. The difference may be attributed to their different mineral compositions. The effect of mineral composition is appreciable, probably because thermal conductivity is much more sensitive to mineral composition than are other physical properties, and because the difference between the conductivity of the solid rock (2.55 $\left.\mathrm{W} / \mathrm{m}^{\circ} \mathrm{C}\right)$ and that of water $\left(0.59 \mathrm{~W} / \mathrm{m}^{\circ} \mathrm{C}\right)$ is relatively small. These reasons also account for the observed broad distribution of the conductivity data.

\section{Electrical Resistivity}

Electrical resistivity and porosity are closely correlated, as shown in Figure 7. The correlation and the low resistivity of these samples compared with the resistivity of dry rocks (Nafe and Drake, 1968; Parkhomenko, 1967) indicate that resistivity and its variation are much 


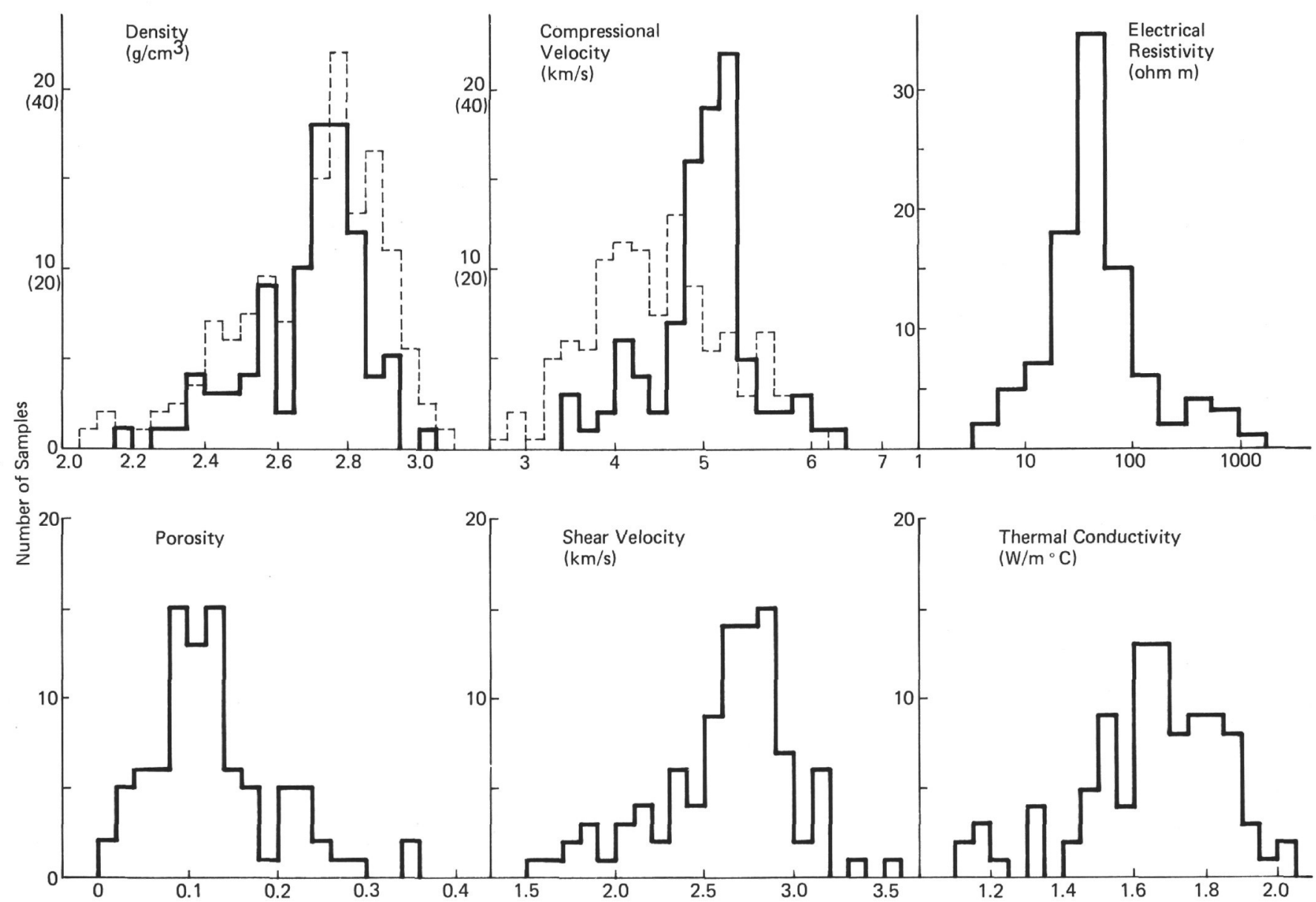

Figure 2. Histograms of the observed physical properties of DSDP Leg 55 basalts: (a) density, (b) porosity, (c) compressional-wave and (d) shear-wave velocities, (e) electrical resistivity, and (f) thermal conductivity. Dotted lines in density and compressional-wave velocity show distribution of the onboard measurement.

TABLE 2

Average Physical Properties of Leg 55 Tholeiites and Alkalic Basalts

\begin{tabular}{|c|c|c|c|c|}
\hline & \multicolumn{2}{|c|}{$\begin{array}{l}\text { Tholeiites } \\
\text { (70 samples) }\end{array}$} & \multicolumn{2}{|c|}{$\begin{array}{l}\text { Alkalic Basalts } \\
\text { (25 samples) }\end{array}$} \\
\hline & Mean & $\begin{array}{l}\text { Std. } \\
\text { Dev. }\end{array}$ & Mean & $\begin{array}{l}\text { Std. } \\
\text { Dev. }\end{array}$ \\
\hline Bulk density $\left(\mathrm{g} / \mathrm{cm}^{3}\right)$ & 2.684 & 0.162 & 2.726 & 0.134 \\
\hline $\begin{array}{l}\text { Porosity } \\
\text { Grain density }\left(\mathrm{g} / \mathrm{cm}^{3}\right)\end{array}$ & 0.140 & 0.072 & 0.098 & 0.053 \\
\hline Compressional velocity $(\mathrm{km} / \mathrm{s})$ & 4.99 & 0.62 & 5.17 & 0.47 \\
\hline Shear velocity $(\mathrm{km} / \mathrm{s})$ & 2.60 & 0.40 & 2.72 & 0.27 \\
\hline Thermal conductivity $\left(\mathrm{W} / \mathrm{m}^{\circ} \mathrm{C}\right)$ & 1.669 & 0.194 & 1.620 & 0.192 \\
\hline Electrical resistivitya (ohm m) & 1.61 & 0.46 & 1.87 & 0.45 \\
\hline
\end{tabular}

${ }^{\mathrm{a}}$ Mean and standard deviation of $\log \left(\sigma^{-1}\right)$.

affected by the salt water (resistivity $=0.23 \mathrm{ohm} \mathrm{m}$ ) in the samples.

The variation of electrical resistivity with water content has been studied extensively for various rock types (cf. Parkhomenko, 1967). The variation is usually expressed by a semi-empirical formula called Archie's law (cf. Keller, 1967, for review). In its general form, Archie's law is expressed as

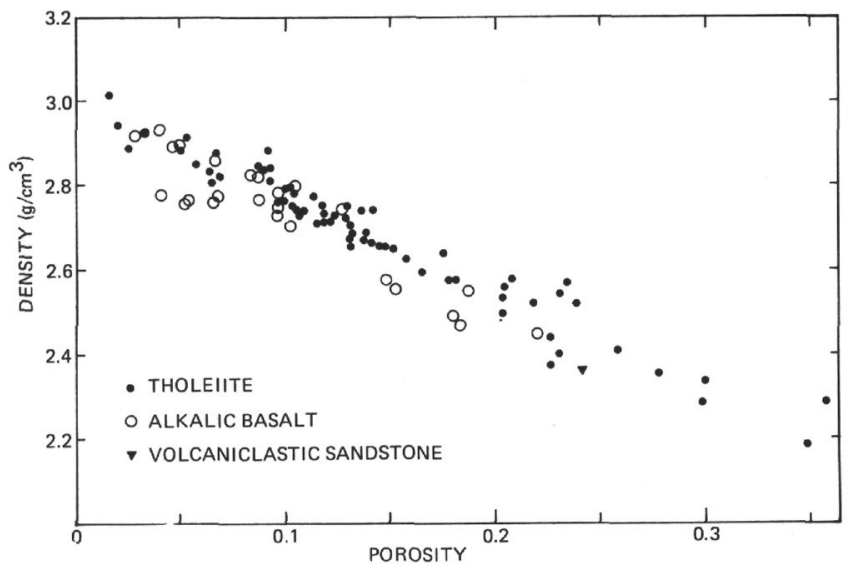

Figure 3. Porosity dependence of bulk density.

$$
\sigma^{-1 / \sigma_{\mathrm{w}}{ }^{-1}}=A \phi^{-n}
$$

where $\sigma^{-1}$ and $\sigma_{\mathrm{w}}{ }^{-1}$ are the electrical resistivity of the water-saturated rocks and pore fluid, respectively; $\phi$ is the porosity; and $A$ and $n$ are empirical parameters determined for each rock type. A least-squares approximation to the present data gives $A=5.09$ and $n=1.67$, where ${\sigma_{\mathrm{w}}}^{-1}$ of $0.23 \mathrm{ohm} \mathrm{m}$ was applied. These values are 


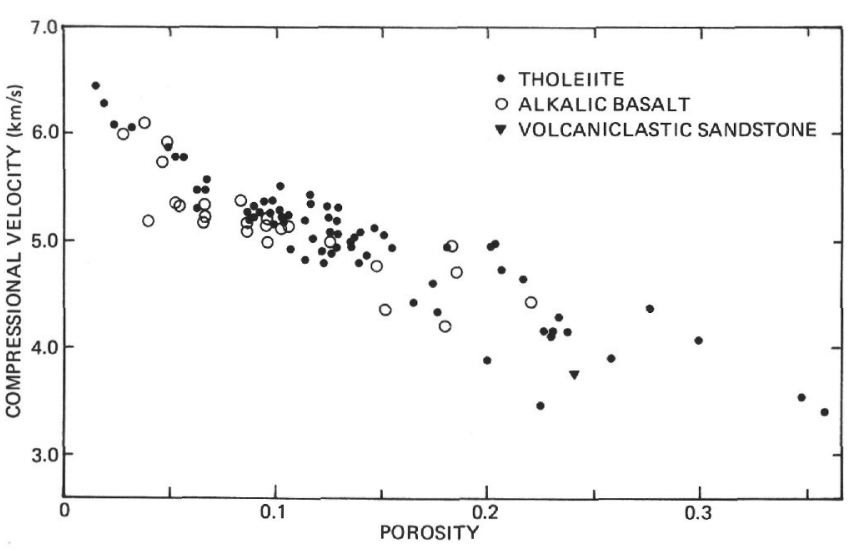

Figure 4. Porosity dependence of compressional velocity.

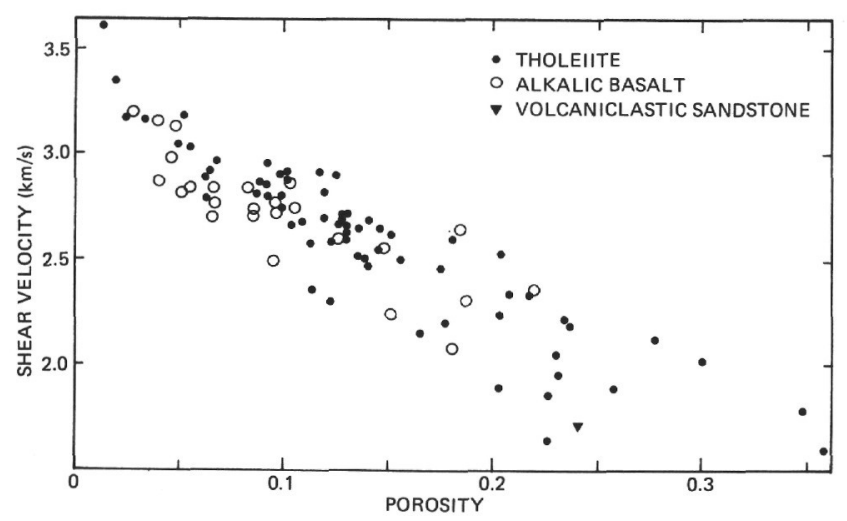

Figure 5. Porosity dependence of shear velocity.

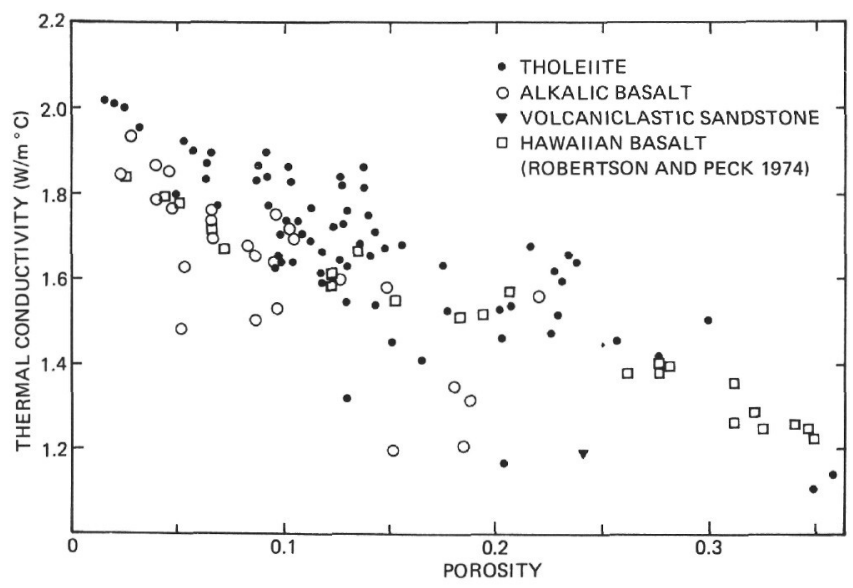

Figure 6. Porosity dependence of thermal conductivity.

comparable to those obtained for highly porous volcanic rocks (Keller, 1967). The parameter $n$ depends on the configuration of the pores. If the electrical conduction is through mutually connected cracks with equal thicknesses, $n=1$. And for conduction through pores that are nearly equidimensional, $n=2$. The present value of 1.67 suggests that the effects of vesicles in the observed resistivity is dominant.

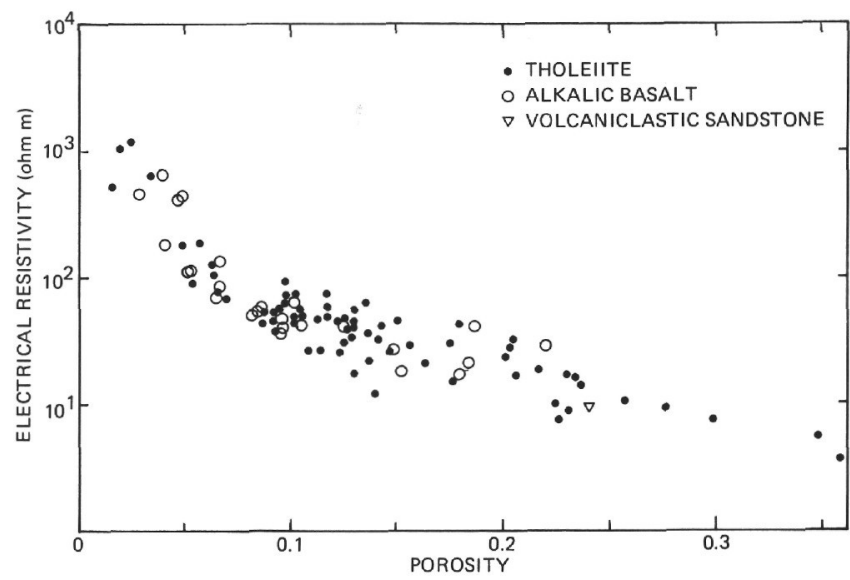

Figure 7. Porosity dependence of electrical resistivity.

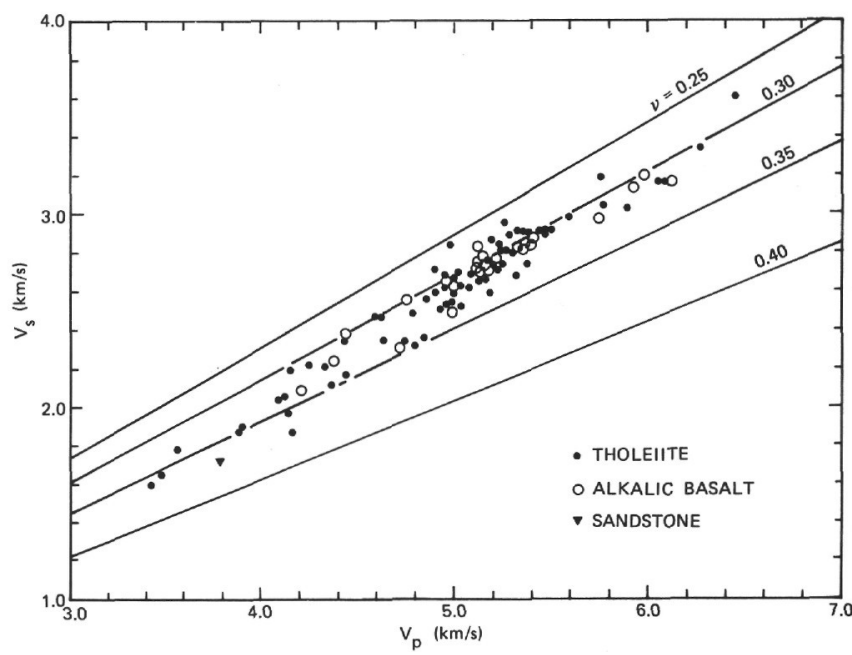

Figure 8. Relation between compressional- and shearwave velocity. Equi-Poisson's ratio ( $\nu$ ) lines for $\nu=$ $0.25,0.30,0.35$, and 0.40 in the diagram are also shown.

The values of electrical resistivity for our seamount samples are comparable to those for sea-floor basalt (Hyndman and Drury, 1976). This does not necessarily mean that their intrinsic resistivity values are the same, because the contribution of rock resistivity to the observed resistivity is negligible. For the same reason, it is not possible to obtain the intrinsic resistivity from our data.

\section{Average Physical Properties of Seamount Basalts}

Hole 433C (Suiko) penetrated nearly 400 meters of basaltic layer. Because of the high recovery $(\sim 65 \%)$ and deep penetration, the samples from this hole can be considered representative of the upper part of a typical seamount. Since this is the first opportunity to obtain and examine an appreciable portion of seamount basalt, it is pertinent to discuss the average physical properties of the samples. Comparison with normal sea-floor basalts is convenient because extensive data are available (cf. Christensen and Salisbury, 1975). 
As discussed in the foregoing, the intrinsic properties and the porosity dependence of the bulk properties of the seamount basalt samples are comparable to those of normal sea-floor basalts. Average properties, however, show some differences. The average properties of the seamount basalts are compared in Table 3 with those of ocean-floor basalts from DSDP Leg 37 (Hyndman and Drury, 1976) and from Legs 51-53 (Hamano, in press). The average porosity of the seamount basalts is larger than that of the oceanic tholeiite, and all the other average properties of the seamount basalt have smaller values than those of the tholeiite. This tendency is reasonable because the bulk physical properties are controlled mainly by the salt water content filling the pore space, and the corresponding physical properties values of salt water are smaller than those of the solid basalts. The larger average porosity of the seamount basalts can be attributed to subaerial eruption, deduced from the petrologic study (Kirkpatrick et al., this volume) and the magnetic study (Kono, this volume). The subaerial eruption may also be responsible for the wider dispersion in values of bulk properties.

\section{SUMMARY AND CONCLUSIONS}

Physical properties were measured on 98 basalt samples obtained during Leg 55. These basalts can be taken as typically representative of the upper parts of the seamounts in the Emperor Seamount chain. Variations in the measured physical properties among the samples result from their water content or porosity. The variations and the intrinsic (pore-free) properties of the seamount basalts are comparable to those of normal sea-floor basalts. The higher average porosity value and the wider dispersion of porosity data for the seamount basalts, reflecting their subaerially erupted origin, result

TABLE 3

Average Physical Properties of the Whole Leg 55 Basalts Compared with Those of Oceanic Tholeiite

\begin{tabular}{|c|c|c|c|}
\hline & Leg 55 & Leg $37^{a}$ & Legs $51-53^{b}$ \\
\hline $\begin{array}{l}\text { Bulk density } \\
\left(\mathrm{g} / \mathrm{cm}^{3}\right)\end{array}$ & $2.695 \pm 0.154$ & $2.795 \pm 0.082$ & $2.785 \pm 0.128$ \\
\hline $\begin{array}{l}\text { Porosity (vol. } \\
\text { fraction) }\end{array}$ & $0.129 \pm 0.067$ & $0.078 \pm 0.041$ & $0.084 \pm 0.055$ \\
\hline $\begin{array}{l}\text { Compressional } \\
\text { velocity }(\mathrm{km} / \mathrm{s})\end{array}$ & $5.037 \pm 0.582$ & $5.94 \pm 0.34$ & $5.48 \pm 0.48$ \\
\hline $\begin{array}{l}\text { Shear velocity } \\
(\mathrm{km} / \mathrm{s})\end{array}$ & $2.632 \pm 0.369$ & $3.27 \pm 0.15$ & $3.10 \pm 0.21$ \\
\hline $\begin{array}{l}\text { Thermal conduc- } \\
\text { tivity }\left(\mathrm{W} / \mathrm{m}^{\circ} \mathrm{C}\right) \\
\text { Electrical resis- }\end{array}$ & $1.656 \pm 0.192$ & $1.66 \pm 0.07$ & $1.80 \pm 0.07$ \\
\hline tivity ${ }^{\mathrm{c}}(\mathrm{ohm} \mathrm{m})$ & 48 & 220 & 120 \\
\hline
\end{tabular}

$\mathrm{a}$ Hyndman and Drury, 1976.
$\mathrm{~b}$ Hamano, in press.

$c_{\text {Geometric mean. }}$ in smaller average physical properties values for these basalts compared with sea-floor basalts.

\section{ACKNOWLEDGMENTS}

We thank Seiya Uyeda for use of the thermal conductivity meter.

\section{REFERENCES}

Christensen, N. I. and Salisbury, M. H., 1975. Structure and constitution of the lower oceanic crust, Rev. Geophys. Space Phys., v. 13, pp. 57-86.

Hamano, Y., in press. Physical properties of basalts from Holes 417D and 418A. In Donnelly, T., Francheteau, J., Bryan, W., Robinson, P., Flower, M., and Salisbury, M., et al., Initial Reports of the Deep Sea Drilling Project, v. 51, 52, 53, Pt. 2: Washington (U.S. Government Printing Office).

Hashin, Z. and Strikman, S., 1963. A variational approach to the elastic behavior of multiphase materials, J. Mech. Phys. Solids, v. 11, pp. 127-140.

Hill, R., 1963. New derivations of some elastic extreme principles. In Progress in Applied Mechanics, The Prager Anniversary Volume: New York (MacMillan), pp. 99-106.

Hyndman, R. D. and Drury, M. J., 1976. The physical properties of oceanic basement rocks from deep drilling on the Mid-Atlantic Ridge, J. Geophys. Res., v. 81, pp. 4042-4052.

1977. Physical properties of basalts, gabbros, and ultramafic rocks from DSDP Leg 37. In Aumento, F., Melson, W. G., et al., Initial Reports of the Deep Sea Drilling Project, v. 37: Washington (U.S. Government Printing Office), pp. 395-402.

Katsube, T. J., Frechette, J., and Collett, L. S., 1977. Preliminary electric measurements of core samples, DSDP Leg 37. In Aumento, F., Melson, W. G., et al., Initial Reports of the Deep Sea Drilling Project, v. 37: Washington (U.S. Government Printing Office), pp. 417-421.

Keller, G. V., 1967. Supplementary guide to the literature on electrical properties of rocks and minerals. In Parkhomenko, E. L. (Ed.), Electrical Properties of Rocks: New York (Plenum Press), pp. 265-308.

Kuster, G. and Toksoz, N., 1974. Velocity and attenuation of seismic waves in two-phase media, I: Theoretical formulations, Geophysics, v. 39, pp. 587-606.

Nafe, J. E. and Drake, C. L., 1968. Physical properties of rocks of basaltic composition. In Hess, H. (Ed.), Basalts, The Poldervaart Treatise on Rocks of Basaltic Composition: New York (Interscience), pp. 483-502.

Parkhomenko, E. I., 1967. Electrical Properties of Rocks: New York (Plenum Press).

Robertson, E. C. and Peck, D. L., 1974. Thermal conductivity of vesicular basalt from Hawaii, J. Geophys. Res., v. 79, pp. 4875-4888.

Walsh, J. B., 1973. Theoretical bounds on the adiabatic compressibility of rocks, J. Geophys. Res., v. 78, pp. 7631-7636.

Watt, J. P., Davies, G. F., and O'Connell, J., 1976. The elastic properties of composite materials, J. Geophys. Res., v. 81 , pp. 541-563. 